\title{
Wild potato species (Solanum section Petota Solanaceae) in the Tunari National Park, Andean Region of Cochabamba, Bolivia
}

\author{
Mario Coca Morante ${ }^{1 *}$, Alejandro Coca-Salazar ${ }^{2}$ \\ ${ }^{1}$ Departamento de Fitotecnia y Producción Vegetal, Facultad de Ciencias Agrícolas, Pecuarias, Forestales y Veterinarias "Martín \\ Cárdenas”, Universidad Mayor de San Simón, Cochabamba, Bolivia; 'Corresponding Author: cocamorante.mario@gmail.com \\ ${ }^{2}$ Centro de Biodiversidad y Genética, Facultad de Ciencias y Tecnología, Universidad Mayor de San Simón, Cochabamba, Bolivia
}

Received 22 December 2013; revised 20 January 2014; accepted 28 January 2014

Copyright (C) 2014 Mario Coca Morante, Alejandro Coca-Salazar. This is an open access article distributed under the Creative Commons Attribution License, which permits unrestricted use, distribution, and reproduction in any medium, provided the original work is properly cited. In accordance of the Creative Commons Attribution License all Copyrights (C) 2014 are reserved for SCIRP and the owner of the intellectual property Mario Coca Morante, Alejandro Coca-Salazar. All Copyright (C 2014 are guarded by law and by SCIRP as a guardian.

\section{ABSTRACT}

The Tunari National Park is located in the Tunari Mountain Range, part of the Cochabamba Range in the Bolivian Andes. The Park is home to species of wild potato (Solanum section Petota Solanaceae), but these are now threatened by human activity. The aims of the present study were: 1) to determine the distribution of wild potato species in the Park, and, 2) to determine the size of their populations. Collection routes were established within the Park, and the species present along them recorded in 2006, 2007 and 2008. Their population sizes were determined in 2008. Four wild potato species were identified: S. capsicibaccatum, S. berthaultii, S. brevicaule and S. toralapanum. S. capsicibaccatum was the most abundant and had the most extensive distribution, followed by $S$. berthaultii; these last two species are likely endemic. The other species, although probably also endemic, were much less widely distributed; some limiting factor(s) would therefore appear to be acting upon them. S. berthaultii showed variations in corolla shape (rotate, pentagonal and semi-stellate) and flower colour (whitish-lilac to blue-lilac). The remaining species showed no apparent intraspecific variation in their morphological characteristics.

\section{KEYWORDS}

Genetic Erosion; Anthropic Activity; Biological Diversity

\section{INTRODUCTION}

The Oriental Andes crossing Bolivia are composed of the Real, Apolobamba, Muñecas, La Paz, Tres Cruces, and Cochabamba Ranges [1]. The last of these is itself made up of several chains, including the Tunari Chain or Tunari Mountain Range [2]. Between 1962 and 1963, an area of these mountains was declared the "Tunari National Park" (TNP) with the aim of preserving the biological diversity of the Andean ecosystem in the Department of Cochabamba. The Park occupies some 6000 ha, and ranges in altitude from 2600 to $4500 \mathrm{~m}$. Sadly, recent years have seen the TNP suffer deterioration caused by human activity; the turning of land over to agriculture, urbanization and fires have been the most destructive forces. Together, these factors have gradually led to a loss of diversity among the native flora.

The TNP is home to a number of wild potato species (Solanum Section Petota Solanaceae) [3]. In 1891, Bang collected wild specimens in the vicinity of Cochabamba which were later described by Bitter as Solanum brevicaule [4]. However, the oldest report of collecting in the Tunari Mountain Range, undertaken by Cárdenas, Dodds and Simonds, is from March 1963. Collecting in the Liriuni and Vizcachas areas and on towards that of Morochata, they took samples of Solanum capsicibaccatum, Solanum toralapanum var. decurrentilobum, S. brevicaule and Solanum sparsipilum [5]. In 1971, Cárdenas, Hawkes, Cribb, Hjerting and Huamán undertook a collecting trip along the Morochata road towards Liriuni, and collected the same species along with Solanum liriunianum [6]. The aims of the present study were: 1 ) to determine the current diversity of wild potato species in 
the TNP, and, 2) to determine the size of these species' populations.

\section{METHODS}

\subsection{Survey Área}

The TNP occupies territory within three provinces of the Department of Cochabamba: Quillacollo (comprising the areas of Quillacollo, Parotani and Tiquipaya), Cercado (home to Cochabamba City and Kanata) and Chapare (home to Sacaba). The human-occupied areas of the TNP are generally located along water courses coming from the mountains. The humidity in these valleys is high, and rich vegetation grows, protected to some extent from wildfires. These areas are, however, also intensely cultivated. These streams and their areas of influence provided the basis for establishing 10 collection routes that were followed upstream into the mountains (Figure 1, Table 1).

\subsection{Collection of Specimens and Determination of Population Sizes}

Specimens of the different wild potato species encountered along the collection routes were collected between January and March (the flowering and maturation period) of 2006, 2007 and 2008. The longitude, latitude and altitude of these collection points were recorded using a GARMIN Global Positioning System 12 device. Between two and six specimens of each species detected at each collection point (which covered areas of between 2 and $6 \mathrm{~m}^{2}$ ) were taken for deposition in herbaria. In 2008 the sizes of the populations of these species were also determined, counting the number of plants per species present.

\subsection{Taxonomic Identification}

The collected specimens were identified following the criteria of Cárdenas, Ochoa and, Hawkes and Hjerting [7] at the moment of collection; these field identifications were later confirmed in the laboratory. Samples of the collected species were deposited in the Martin Cárdenas National Forestry Herbarium (Universidad Mayor de San Simón, Cochabamba, Bolivia).

\section{RESULTS}

\subsection{Collection and Distribution of Wild Species}

The wild potatoes species collected were S. capsicibaccatum, S. brevicaule, Solanum berthaultii and $S$. toralapanum (Figure 2). These were distributed at different points along the 10 collection routes (Figure 3 ). $S$. capsicibaccatum, the most widely distributed, was found on most of the collection routes, followed by $S$. berthaul- tii, S. brevicaule and S. toralapanum. S. capsicibaccatum was concentrated on the Liriuni, Iscaypata, El Ph'asu, Ch'aqhomayu, Taquiña and Tirani routes, and was the most widely distributed on the Ch'aqhomayu route. $S$. berthaultii was only collected at the end of the Parotani, Villa Animas and Pucara Chico routes (Figure 1). S. toralapanum was only collected in the high part of the Liriuni route. S. brevicaule was occasionally recorded in the same places as $S$. capsicibaccatum and S. berthaultii.

S. capsicibaccatum (Figure 2(a)) was found growing in areas with plant cover and high humidity, e.g., among the undergrowth of Eucalyptus plantations (on the Liriuni route) and native Polylepis besseri forest (on the Iscaypata, Ph'asu, Ch'aqhomayu, Taquiña and Tirani collection routes). It was rarely found in open fields. In general, the morphological characteristics of this species (plant shape, leaf shape, flower shape and colour, fruit shape) were coincident with the features described by Cárdenas (1944), Hawkes and Hjerting (1989) and Ochoa (1990).

\subsection{Habitat and Taxonomy}

S. berthaultii (Figure 2(b)) was found on stony soils in drier places at altitudes of $2400-2600 \mathrm{~m}$, growing alongside predominantly xerophytic vegetation (on the Parotani, Villa Animas and Pucara Chico routes) and among spiny shrubs (Prosopis sp., Acacia sp.) and members of the family Cactaceae (Trichorecerus sp., Cleistocactus sp., Opuntia sp., etc.). Specimens were, however, also found in open fields. In general, this species showed morphological characteristics (shape and colour of the leaves and flowers) in agreement with those described by Hawkes and Hjerting (1989) and Ochoa (1990), although some variations were seen with respect to flower colour (from whitish-lilac to blue-lilac) and corolla shape (rotate to rotate pentagonal). The variation seen in the shape of the leaflets was notable; most were elliptical lanceolate, but in some plants the terminal leaflet was broadly elliptical.

S. toralapanum (Figure 2(d)) was only found growing at high altitude on the Liriuni route where the vegetation was dominated by Stipa ichu (a characteristic prairie-forming grass of Andean areas above $3000 \mathrm{~m}$ ).

S. brevicaule (Figure 2(c)) was found growing in humid areas (on the Liriuni, Ch'aqhomayu, Taquiña and Tirani routes) and in dry habitats (along the Parotani, Villa Animas and Pucara Chico routes).

\subsection{Population Sizes}

Populations of different size were recorded at the different collection points along the routes (Figure 3). $S$. capsicibaccatum had the largest populations of all the 


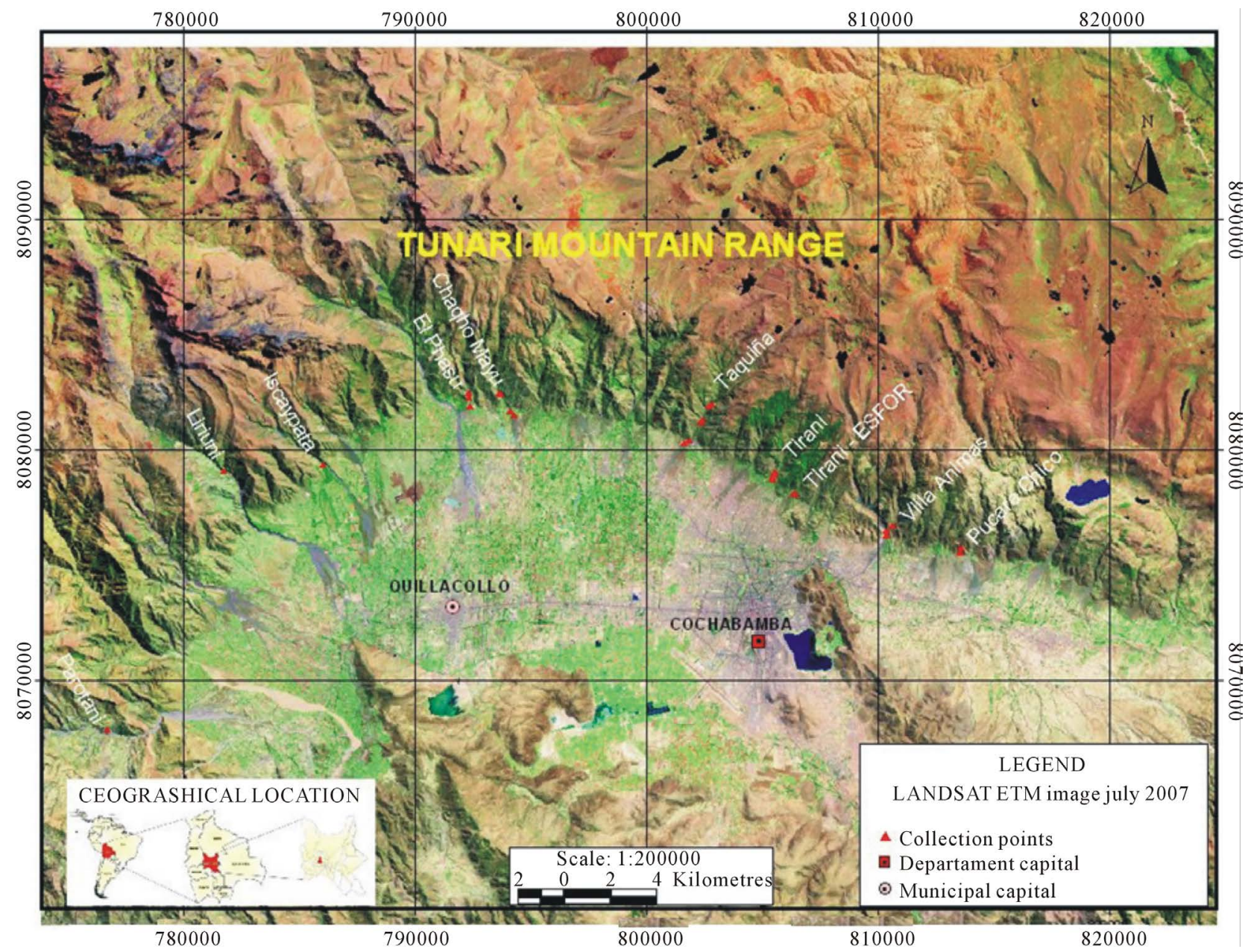

Figure 1. Collection routes (White words) and collection points (Red colour points) in the Tunari National Park, Cochabamba, Bolivia. (Centro de Investigaciones y Servicios en Teledetección-CISTEL, Universidad Mayor de San Simón).

Table 1. Collection routes and collection points: detail of climate, location and collection times etc.

\begin{tabular}{|c|c|c|c|c|c|c|c|}
\hline Collection routes & $\begin{array}{l}\text { Altitude } \\
\text { (m) }\end{array}$ & $\begin{array}{l}\text { Number } \\
\text { Collection }\end{array}$ & Municipality & Province & $\begin{array}{l}\text { Dominant } \\
\text { climate }\end{array}$ & $\begin{array}{l}\text { Collection } \\
\text { Year }\end{array}$ & $\begin{array}{c}\text { Evaluation } \\
\text { year }\end{array}$ \\
\hline & & Points & & & & & \\
\hline Parotani & 2495 & 2 & Parotani & Quillacollo & Arid, dry & 2006, 2007 & 2008 \\
\hline Liriuni & 3158 & 2 & Quillacollo & Quillacollo & Humid & 2006, 2007 & 2008 \\
\hline Iscaypata & 3010 & 3 & Vinto & Quillacollo & Humid & 2006, 2007 & 2008 \\
\hline El Pha'su & 2726 & 4 & Tiquipaya & Quillacollo & Humid & 2007 & 2008 \\
\hline Ch’aqhomayu & 2812 & 9 & Tiquipaya & Quillacollo & Humid & 2006, 2007 & 2008 \\
\hline Taquiña & 2931 & 4 & Cercado & Cercado & Humid & 2007 & 2008 \\
\hline Tirani & 3052 & 4 & Cercado & Cercado & Humid & 2006, 2007 & 2008 \\
\hline Tirani-Esfor & 3003 & 2 & Cercado & Cercado & Humid & 2006, 2007 & 2008 \\
\hline Villa Animas & 2811 & 3 & Sacaba & Sacaba & Arid, dry & 2006, 2007 & 2008 \\
\hline Pucara Chico & 2851 & 2 & Sacaba & Sacaba & Arid, dry & 2006, 2007 & 2008 \\
\hline
\end{tabular}

species detected and found at collection points two and three on the Liriuni and Ch'aqhomayu routes (50 and 46 plants respectively). Along the other routes the populations of this species were $<50$ plants; at some points there were $<10$ plants (Figure 3). In general, S. brevi- caule had few populations of $>50$ plants on the three routes where it was identified (Parotani, Ch'aqhomayu and Taquiña). S. toralapanum was collected from just one small colony. S. berthaultii had a population of 50 plants at the first collection point on the Parotani route, 


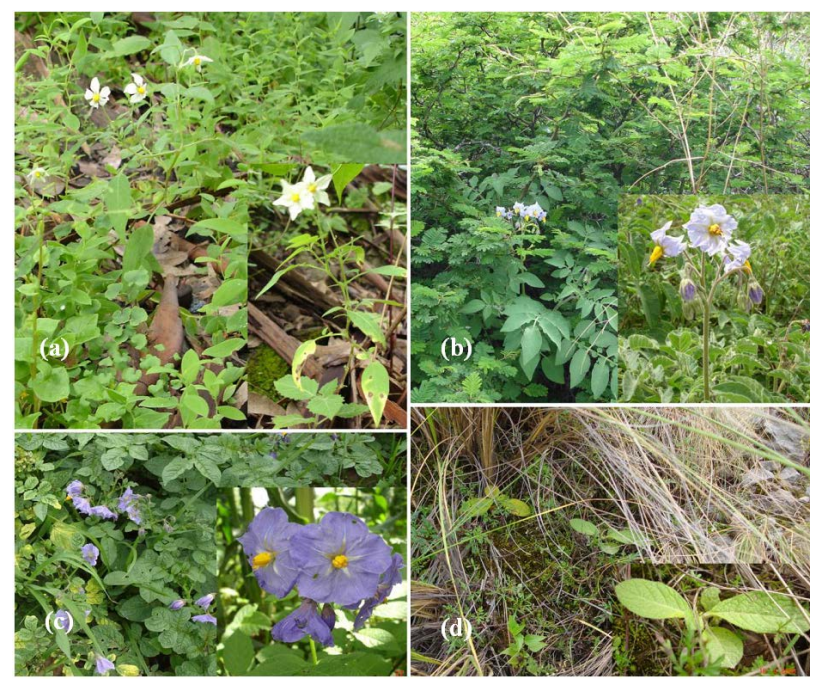

Figure 2. Wild potato species of the Tunari National park: (a) $S$. capsicibaccatum, growing among Eucalyptus sp.; (b) S. berthaultii growing among shrubs; (c) S. brevicaule, growing in an open field; (d) S. toralapanum growing on Stipa ichu grassland.

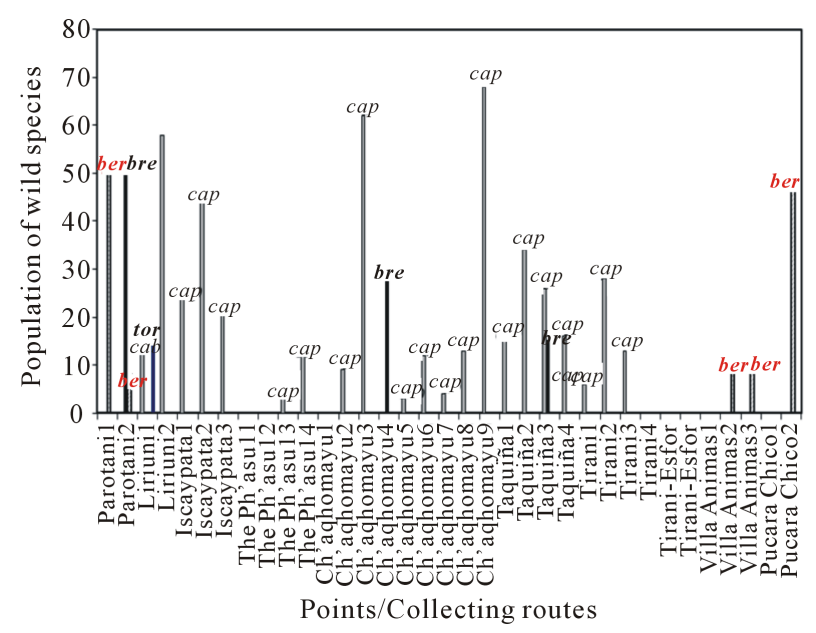

Figure 3. Population size of wild potato species at the different collection points $($ cap $=\mathrm{S}$. capsicibaccatum, bre $=\mathrm{S}$. brevicaule, ber $=S$. berthaultii and tor $=$ S. toralapanum).

and 46 at the second collection point on the Pucara Chico route. The smallest populations were found on the Villa Animas route, with only 8 plants at each of the three collection points (Figure 3). Figure 4 shows the mean population sizes for the different species along the different routes.

\subsection{Altitude}

S. capsicibaccatum was collected from $2726 \mathrm{~m}$ (Liriuni route) to $3307 \mathrm{~m}$ (Taquiña route), S. berthaultii from $2494 \mathrm{~m}$ (Parotani route) to $2956 \mathrm{~m}$ (Pucara Chico route), S. brevicaule from $2510 \mathrm{~m}$ (Parotani route) to $3126 \mathrm{~m}$ (Ch'aqhomayu and Taquiña routes) (sharing its growing space with $S$. capsicibaccatum and $S$. berthaultii), and $S$.

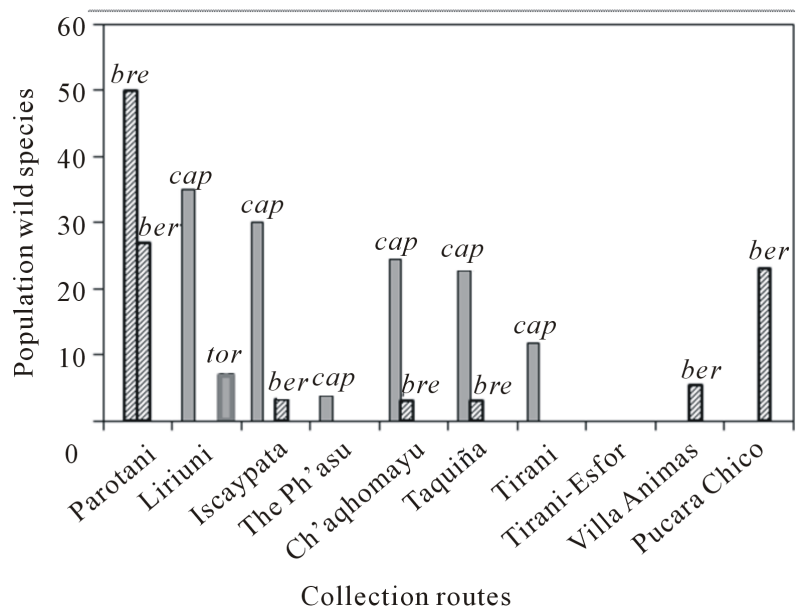

Figure 4. Average population sizes of the wild potatoes species by collection route (cap $=\mathrm{S}$. capsicibaccatum, bre $=S$. brevicaule, ber $=S$. berthaultii and tor $=S$. toralapanum $)$.

toralapanum at $3158 \mathrm{~m}$ (Liriuni route).

\section{DISCUSSION}

The wild potato species collected in the present study were also collected in 1963 and 1971 by Dodds, Simonds and Cárdenas, by Hawkes, and by Cribb, Hjerting and Huamán, although not strictly within the area of the TNP. These would appear to be the only wild potato species in the TNP, although Cárdenas also indicates $S$. sparsipilum and $S$. liriunianum in the area of influence of the Liriuni route. According to Ochoa, S. liriunianum is a synonym of $S$. brevicaule. The collected species grew in different habitats and showed different population sizes. S. berthaultii showed intraspecific morphological variation.

This species has been previously reported on the Liriuni route near Morochata. However, the present results show it to have a wider distribution in the TNP. Some large populations ( $>50$ plants per collection point) were seen, e.g., on the Ch'aqhomayu route, as well as small populations ( $<10$ plants per collection point) (on the Ph'asu and Tirani routes).

Ochoa indicated this species to be abundant in the Departments of Cochabamba and Santa Cruz. Its broad distribution in the TNP suggests it to be an endemic species, with different factors affecting its distribution. The population sizes recorded are suggestive of a gradual reduction in its distribution; according to Quinteros, recent years have seen the TNP suffer deterioration caused by human activity (the turning over of land to agriculture, urbanization and fires have been the most destructive forces). The high humidity along the collection routes favour the survival of this species. Although the exact species and subspecies of the series Circaeifolia are unclear [8], all the present corresponding specimens were classified as $S$. capsicibaccatum. In general, this species 
showed little morphological variation among the different collecting points. Its preference for growing among shrubs and in loose soils with high organic matter contents and better microclimatic conditions of humidity and temperature shows that plant cover is important to its survival. Certainly, these are not the conditions found in open fields, where the species was never detected.

This species is reported for first time in the TNP, although it has been collected at Cerro San Pedro in Cochabamba City. It is remarkable that this species is not found where S. capsicibaccatum grows. Indeed, it was only found at certain points along the Parotani, Villa Animas and Pucara Chico routes. The climate and dominant vegetation (xerophytic) in these areas are similar to those of Cerro San Pedro, as described by Hawkes and Hjerting.

Notable morphological variations were recorded in flower colour and corolla shape, both within populations and among those of the different collection routes. Hawkes and Hjerting described the flowers to be a violet-blue or blue lilac, and the corolla shape to be pentagonal or sub-stellate. However, on the Parotani route, whitishlilac flowers with rotate corollas were seen (Figure 2(b)), and along the Villa Animas and Pucara Chico routes, whitish-lilac and blue-lilac flowers with pentagonal to semi-stellate corollas were observed. Similar variations are reported by Spooner et al. These variations could be product of hybridisation rather than be due to any environmental factor since all the populations grew under similar conditions.

S. brevicaule was collected in 1891 by Bang and in 1963 by Cárdenas, in Cochabamba and on the Liriuni route towards Morochata. On some of the present collection routes it was found growing alongside $S$. capsicibaccatum and $S$. berthaultii, although these populations were small. It may be endemic to the Tunari Mountain Range, with unknown factor(s) affecting its distribution. Hawkes and Hjerting, collected S. toralapanum near the edge of the TNP in the Cochabamba area, but in the present work it was only collected in the high part of the Liriuni route. Indeed, S. toralapanum is recorded as a highland species (>3000 m) by Hawkes and Hjerting, and Ochoa. At these altitudes Solanum acaule Bitter is also reported to grow, though it was not found in the present work.

\section{Conclusion}

In conclusion, it is likely that only four wild potato species grow in the TNP. The population sizes of S. capsicibaccatum and $S$. berthaultii suggest that they are en- demic. Their distributions, however, would appear to be affected by different factors. S. capsicibaccatum is the most widespread species in the central TNP area; $S$. berthaultii, the next most widespread, is mainly found in arid areas. This latter species shows remarkable variations in its morphology. S. brevicaule has a smaller distribution, sharing growing areas with $S$. berthaultii, $S$. capsicibaccatum and $S$. toralapanum in the high areas of the Liriuni route.

\section{ACKNOWLEDGEMENTS}

The authors thank Alejandro Salazar Torrico and Juvenal Zurita Pardo for their help in planning the collection trips, and to the many farmers of the Tunari Mountain Range who guided our walks. Thanks are owed to Freddy Espinoza (Universidad Mayor de San Simón) for their valuable comments and suggestions. Finally, the authors thank the Centro de Investigaciones y Servicios en Teledetección (CISTEL) (Universidad Mayor de San Simón) for producing the map shown in this paper. The authors also thank Adrian Burton for editorial assistance.

\section{REFERENCES}

[1] Montes de Oca, I. (1997) Geography and natural resources of Bolivia. National Academy of Sciences of Bolivia. Editorial Bolivian Offset Ltda, “EDOBOL”, La Paz, $154 \mathrm{p}$.

[2] Quinteros, C.V.R. (2003) Human establishments in the National Park Tunari. Foundation Simón I. Patiño. Geneva-Switzerland, $11 \mathrm{p}$.

[3] Hawkes, J. G. and Hjenting J.P. (1989) The potatoes of Bolivia: Their breeding and evolutionary relationships. Oxford University Press, Oxford.

[4] Ochoa, C.M. (1990) The potatoes of South America: Bolivia. Cambridge University Press, Cambridge.

[5] Cárdenas, M. (1973) Memorias de un naturalista: Viajes a través de los Andes, La Plata, Estados Unidos y Europa. Editorial Don Bosco, La Paz.

[6] Cárdenas, M. (1944) Enumeration of the wild potatoes of Bolivia, description of two new species of Cochabamba. Review of Agriculture (University Cochabamba, Bolivia), 2, 27-37.

[7] Hawkes, J.G. (1997) To database for wild and cultivated potatoes. Euphytica, 93,155-161. http://dx.doi.org/10.1023/A:1002953700049

[8] Spooner, D.M., van der Berg, R.G., García, W. and Ugarte, M. L. (1994) Bolivia potato germplasm collecting expeditions 1993, 1994: Taxonomy and new germplasm resources. Euphytica, 79, 137-148. http://dx.doi.org/10.1007/BF00023585 